\title{
Proximate Composition and Antioxidant Activities of Vegetable Milk from Lotus Seeds (Nolumbo nucifera)
}

\author{
Ace Baehaki ${ }^{1, *}$, Rinto ${ }^{1}$, Muhammad Hendri' ${ }^{2}$, Sabri Sudirman' ${ }^{1}$, Jeny Pusphyta Buana ${ }^{1}$
}

Ace Baehaki ${ }^{1, *}$, Rinto',

Muhammad Hendri², Sabri

Sudirman', Jeny Pusphyta Buana

'Study Program of Fisheries Product Technology, Faculty of Agriculture,

Universitas Sriwijaya, Indralaya, South Sumatera, INDONESIA.

${ }^{2} S$ tudy Program of Marine Sciences, Faculty of Mathematics and Natural Sciences,

Universitas Sriwijaya, Indralaya, South Sumatera, INDONESIA.

\section{Correspondence}

\section{Ace Baehaki}

Study Program of Fisheries Product

Technology, Faculty of Agriculture,

Universitas Sriwijaya, Indralaya, South

Sumatera, INDONESIA.

E-mail: acebaehaki.thi@unsri.ac.id

History

- Submission Date: 01-12-2020;

- Review completed: 11-01-2021;

- Accepted Date: 02-02-2021.

DOI : 10.5530/pj.2021.13.54

Article Available online

http://www.phcogj.com/v13/i2

\section{Copyright}

(C) 2021 Phcogj.Com. This is an open access article distributed under the terms of the Creative Commons Attribution 4.0 International license.

\section{ABSTRACT}

This study aims to proximate composition and antioxidant activities of vegetable milk from lotus seeds (Nolumbo nucifera). The research method in this study used a randomized block design with 3 levels of treatment with 3 repetitions, the treatments used were: $A 0=100 \%$ soybean (Control), $\mathrm{A} 1=$ boiling temperature $80^{\circ} \mathrm{C}, \mathrm{A} 2=$ boiling temperature $90^{\circ} \mathrm{C}, \mathrm{A} 3=$ boiling temperature $100{ }^{\circ} \mathrm{C}, \mathrm{B} 1$ = boiling time $10 \mathrm{~min}, \mathrm{~B} 2=$ boiling time $30 \mathrm{~min}$ and $\mathrm{B} 3=$ boiling time $50 \mathrm{~min}$. The test parameters carried out were proximate composition (water, ash, protein, fat, carbohydrates, and antioxidants) and antioxidant activiy. The results showed the ash content of the lotus seed until the boiling time of 90 min increased, but when the temperature was increased to $100{ }^{\circ} \mathrm{C}$, the ash content decreased. The fat content of lotus seed milk decreased with increasing boiling time. The protein of vegetable milk from lotus seeds tend to increase with the duration of boiling. The result showed the soy milk has the highest activity (control). For lotus seed milk, the highest activity was in lotus seed milk with boiling temperature treatment of $80^{\circ} \mathrm{C}$ and boiling time for $10 \mathrm{~min}$.

Key words: Antioxidant, Lotus seeds, Proximate, Vegetable Milk, Nolumbo nucifera.

\section{INTRODUCTION}

Indonesia has vast swamplands, which are overgrown with underutilized wild plants. Among them, there are many swamp plants that are found, namely the lotus plant (Nelumbo nucifera). Traditionally, the lotus plant (N. nucifera) has been widely used to treat various diseases. Lotus (N. nucifera) contains various substances that are useful for the body such as protein, fat, carbohydrates, carotene, starch, phosphorus, iron, calcium and so on, as well as active compounds such as antioxidants (polyphenols and vitamin C) and also antibacterial compounds. One of the compounds that have antioxidant activity is the phenol group, namely phenolic acids, flavonoids, tannins and lignans.

There are various kinds of nutritional content and bioactive components in lotus (Nelumbo nucifera) plants, so lotus plants can be used as food and beverage ingredients. Milk is a balanced food or drink that has high nutritional value, because it contains almost all food substances such as carbohydrates, protein, minerals and vitamins. The ratio of these substances is perfect so that it is suitable to meet human needs. With the increasing need for animal milk, the price of cow's milk is getting more expensive. Animal milk has high cholesterol levels, which is $250 \mathrm{mg}$ so it is not recommended to consume excessively, especially for someone who is suffering from certain diseases and is allergic to animal protein. In addition, some toddlers are allergic to lactose, so it is recommended to consume other food products that have nearly the same nutritional content as animal milk. Vegetable milk or milk made from grains has nearly the same nutrition as animal milk. Lotus seed extract has antioxidant activity. ${ }^{2}$ The potency of lotus seed extract which has antioxidant activity allows the milk from this lotuas seed to also have antioxidant activity.

Processing of lotus seeds ( $N$. nucifera) into milk is an effort to make diversified products of lotus seed plants. Because it is known that the manufacture of milk is not only with soybean seeds. The processing of milk from lotus and lotus seeds is unknown. Therefore, it is necessary to do this research to find out how the proximate composition and antioxidant activities of vegetable milk of vegetable milk from lotus seeds.

\section{MATERIALS AND METHODS}

\section{Tools and materials}

The equipment used in the research were digital scales, food processor (Philips), thermometer measuring cup, pot, $100 \mathrm{ml}$ milk bottle, stirrer, filter, calico cloth, oven (model selvis lab thermochenter TC-40s (swiss)), dexicator, porcelain cup, dropper, Bunsen, biuret, Erlenmeyer $250 \mathrm{ml}$.

The ingredients that will be used in the manufacture of vegetable milk are lotus seeds, lotus seeds, salt, and water. The chemicals used for the analysis are alcohol, toluene, aquadest, salt, selenium, concentrated $\mathrm{H}_{2} \mathrm{SO}_{4}$, aquadest, $\mathrm{NaOH}, \mathrm{HCl}$, n-hexane, luff schoorl solution, $\mathrm{Na}_{2} \mathrm{~S}_{2} \mathrm{O}_{3}$.

\section{Lotus seed preparation}

The preparation that was carried out before carrying out the research was the manufacture of milk from lotus seeds, namely: Lotus seeds were picked from 
the lake in Sudimampir village, Ogan Ilir Regency, South Sumatra. Lotus seeds are cleaned from their stalks using scissors or a knife. The lotus seeds were removed from the petals one by one. The lotus seed skin is peeled using a knife. The lotus seeds are split in half to take the green shoots inside, so as not to affect the taste and color in making lotus seed milk because the green shoots inside have a bitter taste. Wash lotus seeds clean to prevent dirt from sticking.

\section{Milk production}

Production method of lotus seed milk according to Nirmagustina et al. ${ }^{3}$ which has been modified as follows: Mixed lotus seeds and boiled for $10 \mathrm{~min}$. Ground lotus seeds using a blender and $400 \mathrm{ml}$ of water, at a temperature of $70{ }^{\circ} \mathrm{C}$ for $5 \mathrm{~min}$. The lotus milk was heated to a boil and salt was added by stirring slowly. The lotus milk is filtered using a clean filter, so that no sediment remains in the milk. Lotus and lotus milk is packaged and analyzed.

\section{Water content analysis}

This water content analysis uses the AOAC method, ${ }^{4}$ water content analysis is the process of evaporation of water in a material using heating techniques. This measurement of water content is based on the oven method where the principle of this method is to evaporate the water molecules in the sample. The procedure for analyzing the moisture content is as follows: The porcelain cup to be used is washed and oven for $30 \mathrm{~min}$ at a temperature of $100-105^{\circ} \mathrm{C}$. Then it is cooled in a desiccator to remove moisture and weighed (A). The sample was mashed first until it was the same and after that it was weighed as much as $2 \mathrm{~g}$. The sample was placed in a known weight porcelain dish. (B). The porcelain plate containing the sample was heated using an oven at $105^{\circ} \mathrm{C}$ for $12 \mathrm{~h}$ for the material with high moisture content, then cooled in a desiccator and weighed. Then it was dried again to constant weight (C). The calculation of water content is based on a wet basis with the formula as follows:

$\%$ Water content $=(\mathrm{B}-\mathrm{C}) /(\mathrm{B}-\mathrm{A}) \times 100$

Information:

$\mathrm{A}=$ Weight of empty cup $(\mathrm{g})$

$\mathrm{B}=$ Weight (sample + plate) before drying $(\mathrm{g})$

$\mathrm{C}=$ weight $($ sample + plate $)$ after drying $(\mathrm{g})$

\section{Ash content}

The analysis of the ash content is based on the AOAC method, ${ }^{4}$ by using an oven with the principle of burning a sample or ashes organic materials so that the organic compound burning process will obtain organic residues, which are often known as ash. The ash content analysis procedure is as follows: The porcelain plate to be used is oven for $30 \mathrm{~min}$ at a temperature of $100-105^{\circ} \mathrm{C}$, then the porcelain plate is cooled in a desiccator for $15 \mathrm{~min}$ to remove moisture and then weighed (A). The sample is then weighed as much as $2 \mathrm{~g}$ in a dried cup (B) then the plate containing the sample is burned over a burning flame until it does not smoke and is followed by ashing in a furnace at $550-600{ }^{\circ} \mathrm{C}$ for $9 \mathrm{~h}$. After completing the ashes of the tool used is turned off (of) and the sample is left for several hours. The sample obtained, then cooled in a desiccator for about $30 \mathrm{~min}$ and continued by weighing. The ash content in the sample is determined by the weight of the organic compound that evaporates. The calculation of the percentage of ash content calculated using the formula:

$\%$ Ash content $=\frac{C-A}{B-A} \times 100$

Information:

$\mathrm{A}=$ Weight of empty cup $(\mathrm{g})$
$\mathrm{B}=$ initial weight (sample + plate $)(\mathrm{g})$

$\mathrm{C}=$ weight (sample + plate) after igniting and cooling (g).

\section{Protein content}

Protein testing using the Kjeldahl method. The procedure for testing protein levels is as follows: The sample is weighed on 2 grams of Whatman paper, then the paper is folded and put into the digestion flask. Then added with 2 catalyst tablets and some boiling stones. A total of $15 \mathrm{ml}$ of concentrated $\mathrm{H}_{2} \mathrm{SO}_{4}(95 \%-97 \%)$ and $3 \mathrm{ml}$ of $\mathrm{H}_{2} \mathrm{O}_{2}$ were added to the sample slowly and let stand for $10 \mathrm{~min}$ in the acid chamber. Then the digestion process is carried out at a temperature of $410{ }^{\circ} \mathrm{C}$ for $\pm 2 \mathrm{~h}$ or until the solution is clear. After that, let it stand until it reaches room temperature and add $50-75 \mathrm{ml}$ of distilled water. Boric acid solution $\left(\mathrm{H}_{3} \mathrm{BO}_{3}\right)$ was put into Erlenmeyer as much as 25 $\mathrm{ml}$ to accommodate the distillate. The flask containing the results of digestion is attached to a series of steam distillates. Then $50-75 \mathrm{ml}$ of sodium hydroxide-thiosulfate solution is added. After that, the distillation process is carried out. The distillate product is then stored in an Erlenmeyer which contains a solution of boric acid until it reaches a minimum volume of $150 \mathrm{ml}$ (the result of the distillate turns yellow). Titrate the distillate with $0.2 \mathrm{~N} \mathrm{HCL}$ until it changes color from green to neutral gray.

Calculation of protein content uses the following formula:

Protein content $\%=((\mathrm{VA}-\mathrm{VB}) \mathrm{HCL} \times(\mathrm{N} \mathrm{HCl}) \mathrm{x}(14.007) \mathrm{X} 6.25 \mathrm{X}$ $100 \%) /(\mathrm{W} X 1000)$

Information:

VA: $\mathrm{ml}$ of HCL for sample titration

VB: $\mathrm{ml}$ of HCL for blank titration

N HCL: normality standard HCL used

14.007: atomic weight of nitrogen

6.25: protein conversion factor for fish

W: sample weight

\section{Fat content}

Analysis of fat content using the National Standard Agency method. ${ }^{5}$ The sample entered into the Mojonnier tube was dissolved with ethanol and hydrolyzed with ammonium hydroxide to form free fatty acids which were then extracted using diethyl ether and petroleum ether as organic solvents. The procedure for the fat content assay is as follows: A sample of $10 \mathrm{ml}$ is inserted into the mojonier tube. The sample was added $1.5 \mathrm{ml}$ of $\mathrm{NH}_{4} \mathrm{OH}$ and shaken. The sample was added with $10 \mathrm{ml}$ of ethanol and shaken. The sample was added $25 \mathrm{~mL}$ of diethyl ether and shaken. The samples were added with petroleum ether and shaken for $1 \mathrm{~min}$. The homogeneous sample is allowed to stand until it forms 2 different phases. The sample is separated and poured into a fat flask whose weight has been known. The extraction was carried out again by adding $5 \mathrm{ml}$ of ethanol and $15 \mathrm{ml}$ of diethyl ether each. The sample and the fat flask were evaporated in an oven at $105^{\circ} \mathrm{C}$ until constant weight. The sample and the fat flask were transferred into a desiccator for 15 min, then the sample and the fat flask were weighed until their weight was constant (not more than $0.2 \mathrm{mg}$ or 0.002 ). Fat content is calculated using the following formula.

$\%$ Fat content $=\mathrm{w} 1 / \mathrm{w} 2 \times 100 \%$

Information:

W1: fat pumpkin weight after oven - initial fat pumpkin weight (g)

W2: initial sample weight (g) 
(\%) Fat content $=$

\section{Analysis of carbohydrate content}

Analysis of carbohydrate content used by different by means of 100 (water content + ash content + fat content + protein content).

\section{Antioxidant analysis with DPPH method}

DPPH radical scavenging activity was measured based on methods described in Hanani et al. ${ }^{6}$ as follows: Take $1 \mathrm{ml}$ of sample that has been dissolved in methanol with concentrations of 100 ppm, 200 ppm, 300 ppm and $400 \mathrm{ppm}$ respectively. Then add as much as $2 \mathrm{ml}$ of DPPH $(0.003 \mathrm{~g} / 50 \mathrm{ml}$ of methanol). The mixture is then homogenized with vortex and then incubated at room temperature for 30 minutes. Then measured with a spectrophotometer at a wavelength of $517 \mathrm{~nm}$. Tests were also carried out on blank solutions (DPPH solution with the solvent). The absorbance value obtained is then used to get the percent of free radical capture. The absorption value of DPPH solution before and after the addition of the extract was calculated as percent inhibition (\% inhibition) with the following formula:

$\%$ Inhibition $=[($ Ao - As $) /$ Ao $] \times 100$

Then the calculation results are entered into the regression equation. The IC50 value of the current calculation of $\%$ inhibition is $50 \%$. Y = $\mathrm{aX}+\mathrm{b}$. $^{\text {? }}$

\section{RESULTS AND DISCUSSION}

\section{Water content}

Water content is the amount of water contained in the material which is expressed in percent. Water content is also a very important characteristic of food, because water can affect the appearance, texture and taste of food ingredients. The water content in food also determines the freshness and durability of the food, the high water content makes it easy for bacteria, molds, and yeast to reproduce, so that changes will occur in foodstuffs. ${ }^{8}$ The water content of lotus seed milk with different boiling time and duration can be seen in Figure 1.

The water content of lotus seed milk was almost the same for all treatments (boiling time and time). The water content of lotus seed milk was also almost the same as soy milk as a control. This is probably because the amount of water to boil the lotus seeds is the same.

\section{Ash content}

Ash content is a mineral element as residue left after the material is burned until it is free of carbon elements. ${ }^{9}$ Ash content can also be interpreted as a non-volatile component, which remains in the combustion of organic compounds. Some vitamins and all minerals are water soluble so they can be eliminated along with the liquid used for cooking. The ash content of the lotus seed milk with different boiling time and duration can be seen in Figure 2.

Ash content of lotus seed milk at temperature 80 and $90{ }^{\circ} \mathrm{C}$, there was an increase in ash content until the boiling time was 30 minutes, when the boiling time was increased to 50 minutes, there was an increase in the ash content of the lotus seed milk. In lotus seed milk with a boiling temperature of $100^{\circ} \mathrm{C}$, as the boiling time increased, the ash content of the lotus seed milk also increased.

\section{Fat content}

Fat has a function to improve the physical shape and structure of food, add nutritional value and calories, and provide a savory taste to food ingredients. ${ }^{8}$ Fat content of lotus seed milk with different boiling time and duration can be seen in Figure 3.

Fat content of lotus seed milk at temperature 80 and $90{ }^{\circ} \mathrm{C}$, there was an increase in fat content until the boiling time was $30 \mathrm{~min}$, when the boiling time was increased to $50 \mathrm{~min}$, there was an increase in the ash content of the lotus seed milk. In lotus seed milk with a boiling temperature of $100{ }^{\circ} \mathrm{C}$, a drastic decrease occurred in the boiling time to $30 \mathrm{~min}$ of boiling time, but during the 50 minutes of boiling, the fat content of the lotus seed milk increased again.

\section{Protein content}

Protein is a very important food substance in the body. The availability of protein in the body must be fulfilled and it really depends on the composition of the food ingredients that a person consumes every day. ${ }^{10}$ Protein is an organic compound containing carbon, nitrogen, oxygen, hydrogen atoms, and some of which contain sulfur, phosphorus, iron or other minerals. ${ }^{11}$ The protein content of lotus seed milk with different boiling time and duration can be seen in Figure 4.

The protein content of lotus seed milk at a temperature of $80{ }^{\circ} \mathrm{C}$ showed a slight decrease in protein content, but when the boiling time was

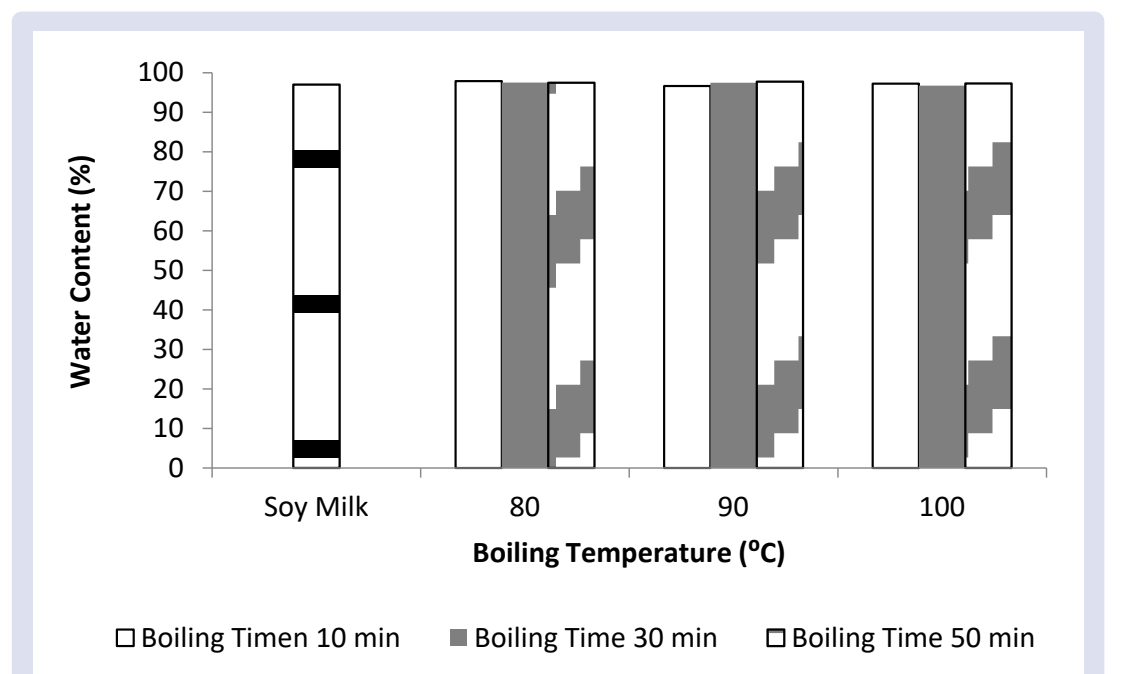

Figure 1: Water content of lotus seed milk with different boiling time and temperatures. 


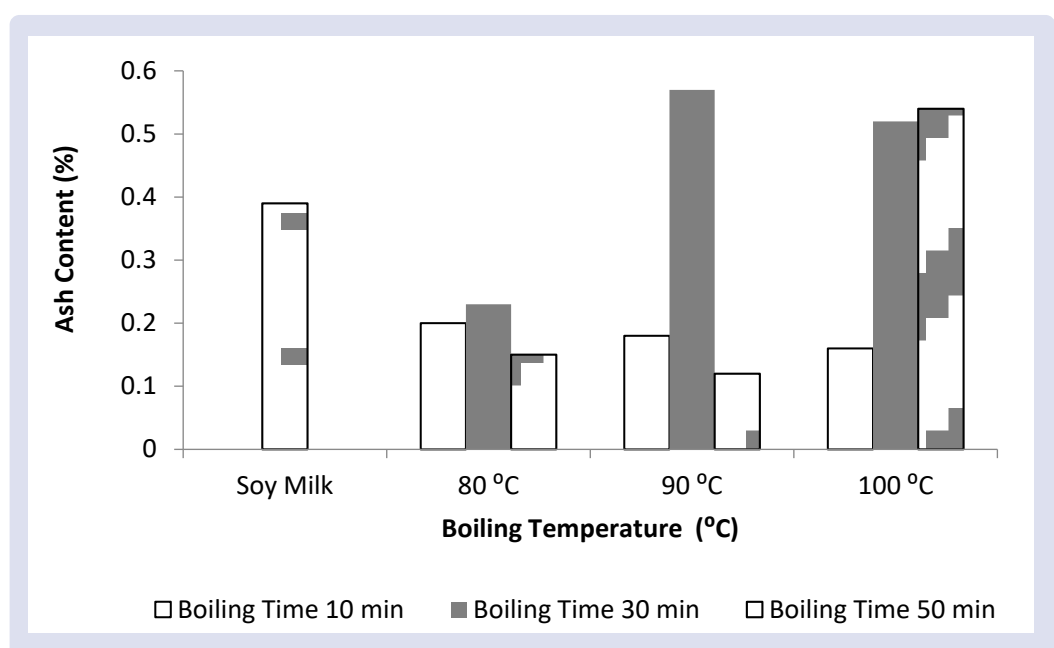

Figure 2: Ash content of lotus seed milk with different boiling time and temperature.

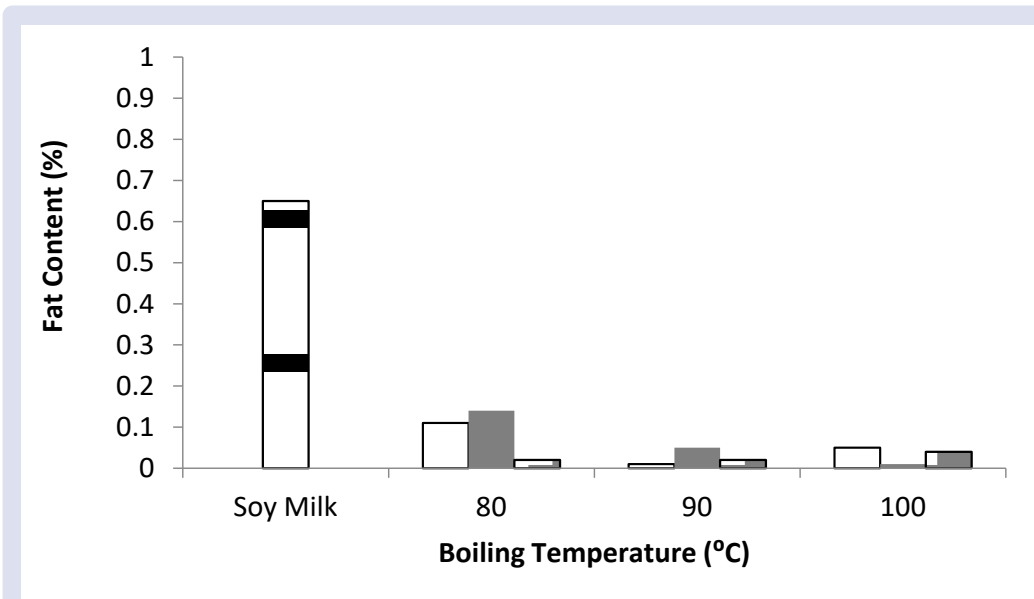

$\square$ Boiling Time $10 \mathrm{~min} \quad$ Boiling Time $30 \mathrm{~min} \quad \square$ Boiling Time $50 \mathrm{~min}$

Figure 3: Fat content of lotus seed milk with different boiling time and duration of treatment.

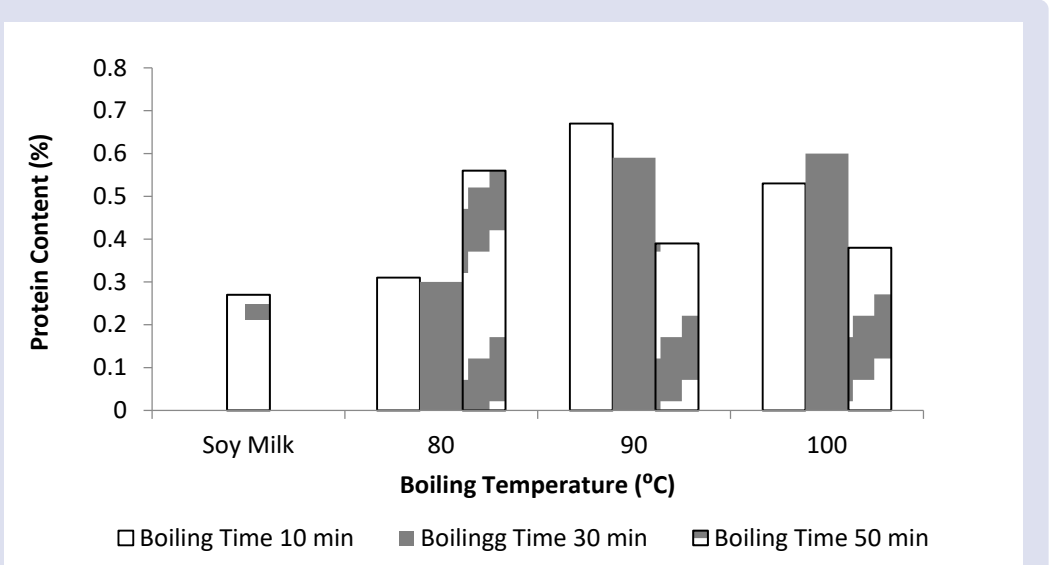

Figure 4: Protein content of lotus seed milk with different boiling time and temperatures. 
increased, the protein content of the lotus milk increased. In lotus seed milk with a boiling temperature of $90{ }^{\circ} \mathrm{C}$, with boiling time to boiling time, there was a decrease in the protein content of lotus seed milk, while for a temperature of $100{ }^{\circ} \mathrm{C}$ in the boiling time of 30 minutes to $50 \mathrm{~min}$ boiling time there was an increase in protein levels but when the boiling time was increased there was a decrease in protein levels this lotus seed milk.

\section{Carbohydrates content}

Carbohydrates are the main source of energy. The recommended daily carbohydrate requirement is $60 \%$ of daily calorie needs. Sources of carbohydrates are rice, corn, bread, sweet potatoes, flour, and the products such as noodles, macaroni and others. ${ }^{12}$ The carbohydrate content of lotus seed milk with different boiling time and duration can be seen in Figure 5.

The carbohydrate content of lotus seed milk at a temperature of $80{ }^{\circ} \mathrm{C}$ increased the carbohydrate content until the boiling time was $50 \mathrm{~min}$. In lotus seed milk with a boiling temperature of $90^{\circ} \mathrm{C}$, a drastic decrease occurred in the boiling time to $30 \mathrm{~min}$ of boiling time, but during the 50 min of boiling, the fat content of the lotus seed milk increased again. For boiling temperature of $100{ }^{\circ} \mathrm{C}$, there was an increase until the boiling time was $30 \mathrm{~min}$ but after $30 \mathrm{~min}$ there was a decrease in carbohydrate comtent.

\section{Antioxidant activity}

The mechanism of antioxidant compounds against DPPH radicals is a reduction reaction..$^{13}$ Proton donations cause DPPH radicals (purple) to non-radical (colorless) compounds. This activity can be observed in decreasing absorbance by spectrophotometer. The results obtained were calculated using linear equations, percent inhibition as $\mathrm{Y}$ axis and sample concentration as X axis. Calculating IC50 by looking at the ability of antioxidant compounds in inhibiting free radicals at 50\% percent inhibition. $\mathrm{IC}_{50}$ of lotus seed milk with different boiling time and temperature can be seen in Figure 6.

Result of antioxidant activity with DPPH method interpreted within parameters of $\mathrm{IC}_{50} . \mathrm{IC}_{50}$ of lotus seed milk shows that the higher the temperature and boiling time, the higher the IC50. An extract or food ingredient has high activity if its $\mathrm{IC}_{50}$ is low. Figure 6 shows that soy milk has the highest activity (control). For lotus seed milk, the highest activity was in lotus seed milk with boiling temperature treatment of 80 ${ }^{0} \mathrm{C}$ and boiling time for $10 \mathrm{~min}$.

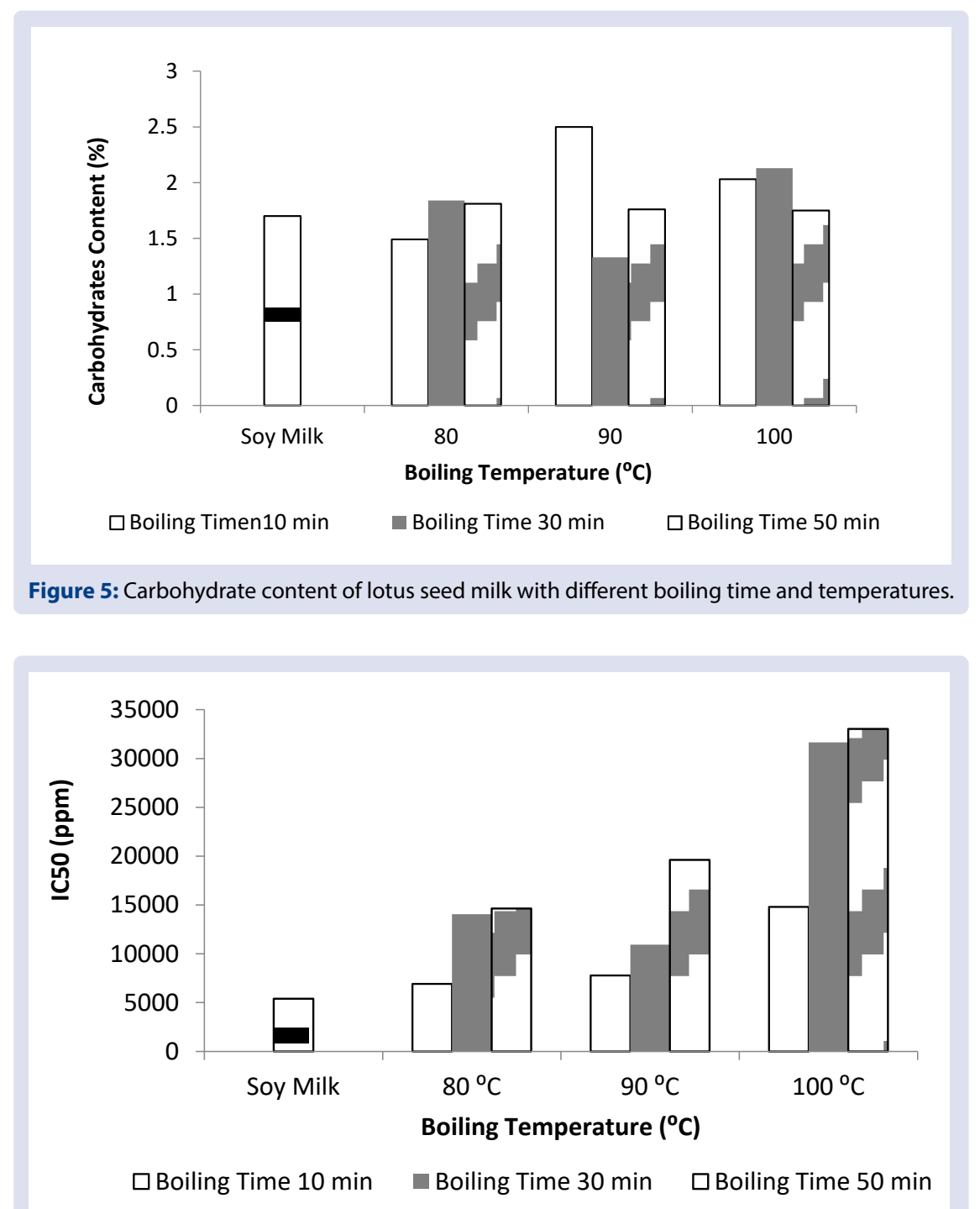

Figure 6: Antioxidant activity of lotus seed milk with different boiling time and temperature. 


\section{CONCLUSION}

Proximate analysis showed that the water content of lotus seed milk tended to increase with increasing boiling time. The ash content of the lotus seed until the boiling time of 90 minutes increased, but when the temperature was increased to $100{ }^{\circ} \mathrm{C}$, the ash content decreased. The fat content of lotus seed milk decreased with increasing boiling time. The levels of vegetable milk protein from lotus seeds tend to increase with the duration of boiling. The result showed the soy milk has the highest activity (control). For lotus seed milk, the highest activity was in lotus seed milk with boiling temperature treatment of $80{ }^{\circ} \mathrm{C}$ and boiling time for $10 \mathrm{~min}$.

\section{ACKNOWLEDGMENTS}

The research/publication of this article was funded by DIPA of Public Service Agency Universitas Sriwijaya 2020. SP DIPA023.17.2.677515/2020, revision 01, On March 16, 2020. In accordance with the Rector's Degree Number: 0685/UN9/SK.BUK.KP/2020, On July 15, 2020.

\section{REFERENCES}

1. Wu L, Hsu, H, Chen Y. Antioxsidant and antiproliferative actives of red pitaya. Food Chem. 2006;95:319-27.

2. Baehaki A, Lestari SD, Apriani W. Phytochemical screening and antioxidant activity of seeds extract of water plant (Nymphaea stellata and Nelumbo nucifera). J Chem Pharm Res. 2015;7(11):221-4.
3. Nirmagustina DE, Rani $H$. Pengaruh jenis kedelai dan jumlah air terhadap sifat fisik, organoleptik dan kimia susu kedelai. J Teknol Industri Hasil Pertanian. 2013;2:168-74.

4. AOAC. Official Methods of Analysis. Assosiation of Official Chemist. Virgiana (USA). 2005.

5. National Standardization Agency. How to test food and beverage. SNI 01-2891-1. Jakarta (IDN). 1992.

6. Hanani E, Moneim B, Sekarini R. Identification of antioxidant compounds in the sponge Callispongia sp of the Thousand Islands. Magazine Pharm Sci. 2005;2:127-33.

7. Zuhra C, Juliarti BT, Herlince, S. Antioxidant Activity of Flavonoid Compounds from Katuk Leaves (Sauropus androgynus (L) Merr.). J Biologi Sumatra. 2008;3(1):7-10.

8. Winarno FG. Food Chemistry and Nutrition. Jakarta. Gramedia Pustaka Utama. 2004

9. Soebito S. Pharmacy Analysis. Yogyakarta. UGM Press. 1998.

10. Kartasapoetra G, Marsetyo H. Nutrition Science Correlation of Health Nutrition and Work Productivity. Jakarta: Rineka Cipta. 2008.

11. Sudarmaji S. Analytical Procedures for Food and Agricultural Ingredients. Yogyakarta. Liberty. 1997.

12. Soenardi T. Alternative Food for National Food Security. Jakarta. Kompas. 2002.

13. Miksusanti M, Elfita E, Hotdelina S. Antioxidant Activity and Properties of Mixed Color Stability Ethyl Acetate Extract of Mangosteen Skin (Garcinia mangostana L.) and Secang Wood (Caesalpinia sappan L.). Chemistry Department, Universitas Sriwijaya. Indralaya. 2012.

\section{GRAPHICAL ABSTRACT}

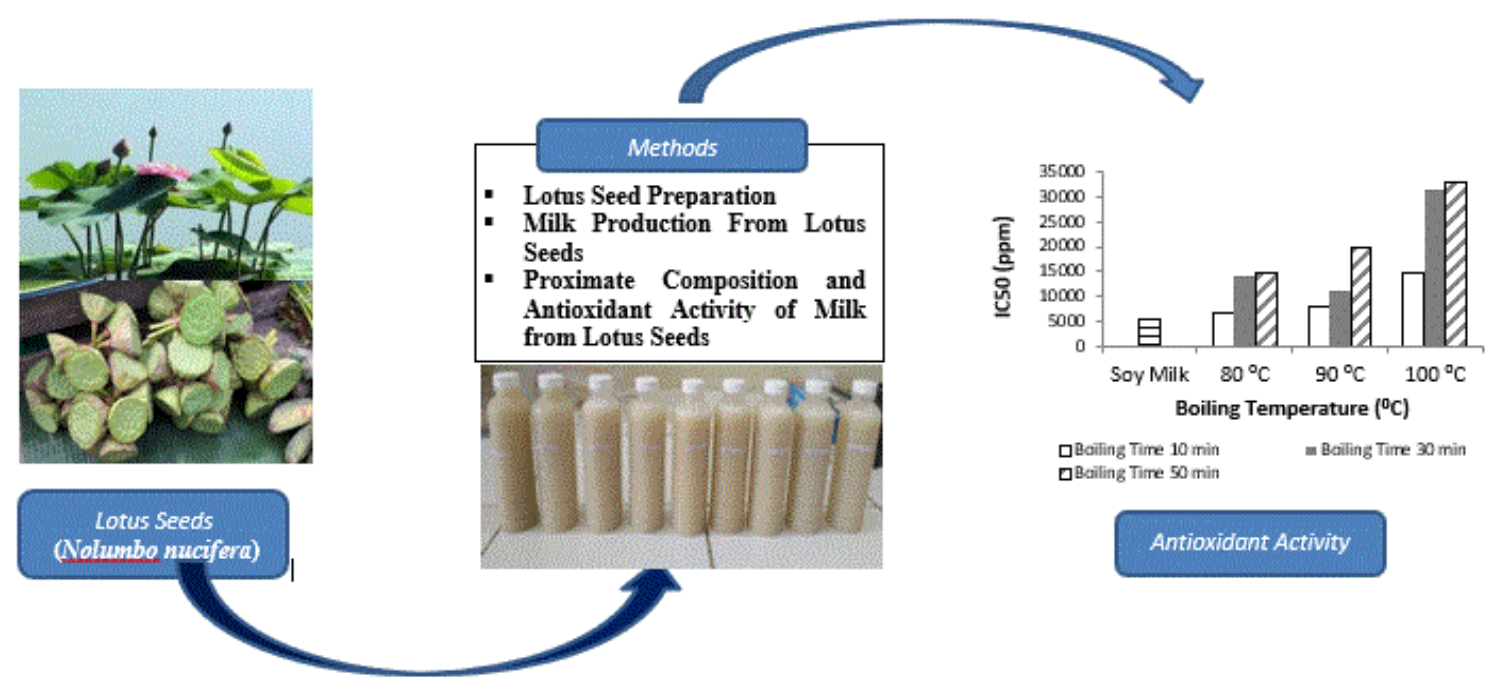



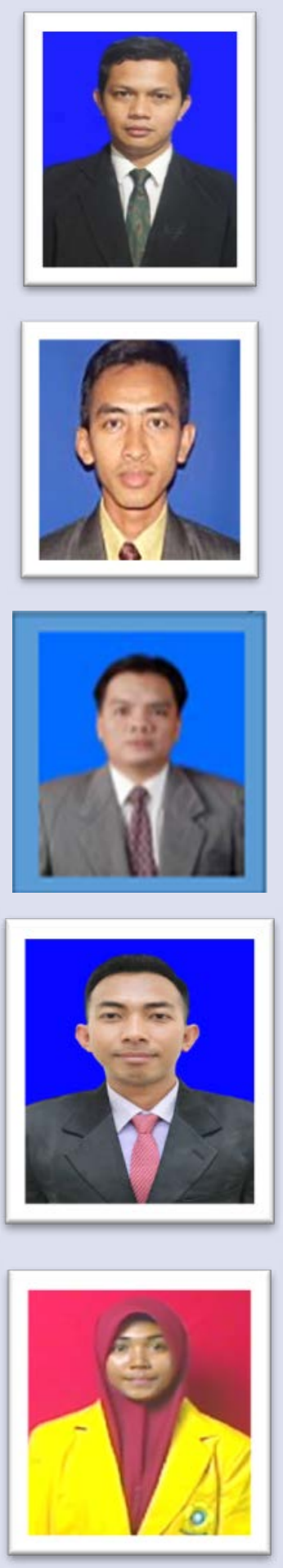

Dr. Ace Baehaki, S.Pi, M.Si, Associate Professor, Department of Fisheries Product Technology, Faculty of Agriculture, Sriwijaya University since 2001. His research area focuses on biological screening and bioactive activity of natural products from aquatic resources.

Dr. Rinto, S.Pi, M.P, Associate Professor, Department of Fisheries Product Technology, Faculty of Agriculture, Sriwijaya University since 2001. His research area focuses on microbiology of fishery product.

Dr. Muhammad Hendri, S.T, M.Si, Assistant Professor, Department of Marine Sciences, Faculty of Mathematics and Natural Sciences, Sriwijaya University. His research area focuses on bioactive activity of natural products from aquatic resources.

Sabri Sudirman, S.Pi, M.Si, Ph.D, Lecturer, Department of Fisheries Product Technology, Faculty of Agriculture, Sriwijaya University. His research area focuses on cellular immunology.

Jeny Pusphyta Buana, The researcher, Department of Fisheries Product Technology, Faculty of Agriculture, Sriwijaya University. Her research area focuses on fisheries product technology.

Cite this article: Baehaki A, Hendri M, Sudirman S, Buana JP. Proximate Composition and Antioxidant Activities of Vegetable Milk from Lotus Seeds (Nolumbo nucifera). Pharmacog J. 2021;13(2): 427-33. 